Acta Horticulturae et Regiotecturae 1

Nitra, Slovaca Universitas Agriculturae Nitriae, 2020, pp. 17-20

\title{
QUALITY PARAMETERS OF KIWIBERRIES GROWN IN THE CZECH REPUBLIC
}

\author{
Miroslav HORÁK \\ Mendel University in Brno, Czech Republic
}

\begin{abstract}
The present study evaluated the quality of kiwiberries produced in the territory of the Czech Republic in 2018 and 2019. Actinidia arguta is a very hardy and flexible species which can produce fully ripe fruits even in the setting of moderate climatic zones unlike commercially available $A$. chinensis as a variety which needs a longer season with higher temperatures to become fully ripe. Once harvested, the fruit was studied for soluble solids content, titratable acidity, antioxidant activity and the content of malic, citric and ascorbic acids. Unlike commercially available kiwifruits, kiwiberries lack hair and can be consumed unpeeled. The results of the present study confirmed the notable potential of kiwiberries consisting namely in the levels of antioxidants present in the skin of the fruit. Kiwiberry fruits feature a higher level of acidity than is common in conventional commercial varieties of $A$. chinensis as citric acid is the type of acid prevailing in the fruit at all times.
\end{abstract}

Keywords: kiwiberry, skin, antioxidant activity, Actinidia arguta

Kiwiberry is a member of the same genus as kiwifruit and presents a species of fruit possessing a great potential to expand the segment of food with increased content of biologically active substances on markets around the world. The commercial production of kiwiberry is more recent than that of kiwifruit; it had not started until the 1980s (Debersaques et al., 2015). Currently, New Zealand, USA, Chile, China and Australia are major global producers of kiwiberry along with some of European countries such as France, Belgium or Germany (Latocha, Vereecke and Debersaques, 2018).

A. arguta is among the most widespread species of the Actinidia genus. The fruit is smooth and lacks hairs; it weighs $5-10 \mathrm{~g}$ and is much smaller than the commercially available kiwifruit. While $A$. arguta is mostly bright green in colour, it may also be pale green, pink up to bright dark red or violet; sometimes, the colour may change during the storage period (Ferguson, Testolin, Huang 2016). The great resistance to frost is typical for kiwiberries when compared with the better known kiwifruit (Drzewiecki et al. 2016). Kiwiberry is richer in taste than kiwifruit; it also features a distinct, aromatic manifestation of tropical fruits. With the positive health effects of the substances contained in the fruit (Rush et al. 2006), kiwiberry is often referred to in the context of superfoods (Ferguson and Ferguson, 2003, Lim, 2012). Wojdyło et al. (2017) report that with the high representation of substances kiwiberry is considered a functional food and ranked as one of the most nutritious fruits globally. For its high levels of phenolic and mineral substances, chlorophylls, carotenoids and ascorbic acid, the fruit is often used in Chinese traditional medicine (Dawes and Keene, 1999; Nishiyama, Fukuda and Oota, 2005).

\section{Material and method}

\section{Experimental material}

The experimental material comprised of two varieties of Actinidia arguta, 'Issai' and 'Ananasnaya,' both grown at a site in Lednice, Czech Republic; as the fruits were ripening in almost identical periods, both varieties were harvested in October decade 3 and 2 in 2018 and 2019, respectively. In both cases, fruits were harvested when they were fully coloured and reached both the size and the degree of hardness corresponding to that variety. The fruits were picked manually and once harvested, they were stored at $-28{ }^{\circ} \mathrm{C}$ until further processing. For comparison, Actinidia chinensis fruits (the varieties of 'Hayward' and 'Soreli') were bought in available commercial shopping chains; these counted 50 fruits in both 2018 and 2019.

Prior to the analysis, the fruits were removed from the freezer and left at a room temperature until they thawed. Subsequently, the skin was removed from each of the fruits and weighed. Each of the samples consisted of 10 fruits in triplicate, i.e. a total of 30 fruits for each of the A. arguta varieties. For Actinidia chinensis, it involved 10-15 fruits in triplicate, i.e. a total of 30-45 fruits.

\section{Soluble solids}

The soluble solids content (SSC) was established using a digital refractometer of PR-32 $\alpha$ (Atago, Japan). The fresh fruits were crushed to obtain juice which was subsequently measured. The resulting value was expressed in ${ }^{\circ}$ Brix degrees.

Contact address: Miroslav Horak, Mendel University in Brno, Faculty of Horticulture, Department of Post-Harvest Technology of Horticultural Products, Valtická 337, 69144 Lednice Czech republic, Phone: +420 519367 268, e-mail: miroslav.horak@mendelu.cz 


\section{Titratable acidity}

To determine titratable acidity (TA), the fresh fruits were homogenised, $5 \mathrm{~g}$ were removed from the homogenate, $10 \mathrm{ml}$ of water added to the same and total titratable acidity established through the method of potentiometric titration. The obtained values were recalculated as the citric acid equivalent and then recalculated and specified in $\mathrm{g}$ per $100 \mathrm{~g}$ of fresh matter.

\section{Organic acids}

Each sample was diluted by demineralised water (the $1: 10$ proportion) and subsequently filtered through a micro filter, grain size $0.2 \mu \mathrm{m}$. Concentrations of malic, citric and ascorbic acid were determined using an HPLC system with the Chrom SDS 150 pump, thermostat (at $30^{\circ} \mathrm{C}$ ) and the Thermo-Spectra System UV 6000 LP DAD Detector (Thermo, USA). The used column: Prevail $5 \mu \mathrm{m}$ Organic Acid 110A HPLC Column $250 \times 4.6 \mathrm{~mm}$, mobile phase $25 \mathrm{mM} \mathrm{KH}_{2} \mathrm{PO}_{4 \prime}$ flow: $1 \mathrm{ml} \cdot \mathrm{min}^{-1}$. The absorbance of the acids was set at a wavelength of $210 \mathrm{~nm}$. Determining the concentration employed 10-point calibration system using tartaric acid and malic acid standards. Sample volume was $20 \mu \mathrm{l}$.

\section{Antioxidant activity}

Determination by means of the FRAP (Ferric Reducing Antioxidant Power) method was done in a pH 3.6 acetate buffer ( $23 \mathrm{mM}$ sodium acetate trihydrate in a solution of $34 \mathrm{mmol}^{-\mathrm{I}^{-1}}$ acetic acid). The reaction mixture contained $12 \mathrm{mmol}^{\mathrm{I}^{-1}}$ of $\mathrm{FeCl}_{3}$ solution, $10 \mathrm{mmol}^{-1}$ of 2,4,6-tris(2pyridyl)-s-triazine in $40 \mathrm{mmol}^{-1} \mathrm{I}^{-1}$ of $\mathrm{HCl}$ solution and a buffer in a ratio of $1: 1: 10.2 \mathrm{ml}$ of the reaction mixture were mixed with $25 \mu$ of a diluted sample $(5 x)$ with deionized water in a disposable plastic cuvette $(10 \mathrm{~mm})$ and the obtained solution was measured using a Helios $\beta$ spectrophotometer after 10 minutes at a wavelength of $593 \mathrm{~nm}$.

For the DPPH method, $1.9 \mathrm{ml}$ of DPPH (2.2-diphenyl-1picrylhydrazyl) a radical solution in methanol $\left(0.1 \mathrm{mmol}^{-1}{ }^{-1}\right)$ was mixed with $0.1 \mathrm{ml}$ of $5 \times$ diluted sample with deionized water in a disposable plastic cuvette $(10 \mathrm{~mm})$. Absorbency at $515 \mathrm{~nm}$ was measured after $30 \mathrm{~min}$ using the Specord 50 plus (Analytik Jena AG, Germany) spectrophotometer.

The resulting values of antioxidant activity (Trolox equivalents) for both methods were related to the same molar mass of the studied compounds and Trolox to make them mutually comparable.

\section{Statistical analysis}

Analysis of variance was performed and means were compared by the Tukey's multiple range test of significant difference $(p<0.05)$. Statistical analyses were performed using the software Statistica 12.

\section{Results and discussion}

The results of the two-year observation made it evident that within the respective years the studied parameters exhibit certain deviations; however, given that the deviations were not very significant, both years can be identified as very similar. The size of the fruits is the underlying quality parameter; in this study, it was determined by means of weight. While the average fruit weight did not exceed $7.3 \mathrm{~g}$ for Actinidia arguta, the weight of Actinidia chinensis fruits reached considerably more than $100 \mathrm{~g}$ (Table 1). However, as the small size of Actinidia arguta fruits is typical for this species, the weight of fruits is essentially no different than values identified by other authors (Zaouay et al., 2012; Wojdyło et al., 2017; White et al., 2005). For both of the A. arguta varieties, fruits were smaller in 2018 (by more than $0.7 \mathrm{~g}$ ). The pulp to skin ratio is higher in the A. arguta fruit where the skin presents a higher proportion of weight out of the total fruit than it is with the $A$. chinensis fruit. The detected results match those achieved as a part of another study (Latocha, Łata and Stasiak, 2015).

The highest amount of sugar, or, the highest level of soluble solids, was determined in the 'Issai' fruit in 2019; in the same year, however, the 'Ananasnaya' fruit reached high values, too; as well, a relatively high value was measured for commercially available 'Soreli' fruits (Table 1). In comparison with the commercially available species, A. arguta fruits exhibit corresponding soluble solids levels. The same conclusion was reached by authors as a part of other studies (Wojdyło et al., 2017; White et al., 2005; Krupa, Latocha and Liwin' ska, 2011). If conditions are appropriate, fruits are capable of generating large quantities of sugar even in rather cold settings. Based on the lower soluble solids value and, simultaneously, the higher

Table 1 Fruit, flesh, peel weight, soluble solids and titratable acidity in Actinidia fruit

\begin{tabular}{|c|c|c|c|c|c|c|c|}
\hline \multirow[t]{2}{*}{ Species } & \multirow[t]{2}{*}{ Variety } & \multirow[t]{2}{*}{ Year } & \multicolumn{3}{|c|}{ Weight (g) } & \multirow[t]{2}{*}{ SSC ( ${ }^{\circ}$ Brix) } & \multirow[t]{2}{*}{ TA (\%) } \\
\hline & & & fruit & flesh & peel & & \\
\hline \multirow{4}{*}{ Actinidia arguta } & 'Ananasnaya' & 2018 & $6.42^{\mathrm{a}}$ & $5.72^{\mathrm{a}}$ & $0.65^{\mathrm{a}}$ & $11.58^{\mathrm{b}}$ & $1.20^{\mathrm{d}}$ \\
\hline & 'Issai' & 2018 & $6.48^{\mathrm{a}}$ & $6.08^{\mathrm{a}}$ & $0.37^{\mathrm{a}}$ & $12.11^{\mathrm{b}}$ & $1.22^{\mathrm{d}}$ \\
\hline & 'Ananasnaya' & 2019 & $7.29^{b}$ & $6.27^{\mathrm{a}}$ & $0.79^{\mathrm{a}}$ & $13.98^{c}$ & $1.03^{c}$ \\
\hline & 'Issai' & 2019 & $7.18^{b}$ & $6.76^{\mathrm{b}}$ & $0.37^{\mathrm{a}}$ & $14.60^{d}$ & $1.02^{c}$ \\
\hline \multirow{4}{*}{ Actinidia chinensis } & 'Hayward' & 2018 & $95.00^{d}$ & $88.8^{c}$ & $6.60^{c}$ & $10.18^{\mathrm{a}}$ & $0.84^{b}$ \\
\hline & 'Soreli' & 2018 & $77.52^{c}$ & $70.70^{d}$ & $5.80^{b}$ & $10.01^{\mathrm{a}}$ & $0.81^{b}$ \\
\hline & 'Hayward' & 2019 & $112.3^{\mathrm{e}}$ & $102.8^{e}$ & $9.44^{d}$ & $10.09^{\mathrm{a}}$ & $0.85^{\mathrm{b}}$ \\
\hline & 'Soreli' & 2019 & $85.43^{d}$ & $78.65^{d}$ & $6.60^{c}$ & $13.36^{c}$ & $0.56^{\mathrm{a}}$ \\
\hline
\end{tabular}

Different uppercase letters next to values indicate significant differences in columns $(p<0.05)$ 
value of titratable acidity in fruits, 2018 can be identified as a less appropriate year for A. arguta fruit to ripen. 'Issai' was assessed to contain a relatively high value (1.22\%); an almost identical level of 1.2 was identified for 'Ananasnaya' (Table 1). While the larger acidity is typical for $A$. arguta varieties, when years are warmer, they are capable of reducing the level of acidity to below $1 \%$ as confirmed for 'Ananasnaya' in 2019. For acidity, citric acid is represented to the largest extent in any of the 4 varieties studied. The fruits also contain malic acid, the proportion of which is considerably lower in the pulp than in the skin with respect to citric acid. This differing proportion was largely observed for the 'Hayward' variety when the pulp contains more than 2.5-fold higher amount of malic acid than that of citric acid while in the skin both of the acids are present in nearly identical concentrations. This tendency was observed for all of the varieties; it was, however, exhibited in none of the samples to such a degree as it was for the variety mentioned above, i.e., 'Hayward' (Table 2). Similar citric acid concentrations in A. arguta were measured by other authors as well (Boyes, Strübi and Marsh 1996; Zhou-Li et al. 2013; Latocha, 2017).

Ascorbic acid is another acid of those studied which is significantly involved in the health benefits of kiwi fruit; it is generally considered as quite a good source of the acid as was confirmed through the results of the present work. Overall, it can be stated that a higher ascorbic acid concentration was the one observed in the pulp of any of the studied varieties, which is in conflict with the study (Latocha, Łata and Stasiak, 2015), where an opposite trend was observed, i.e., a higher ascorbic acid concentration in the skin compared with the pulp. Similar ascorbic acid concentrations in the fruit are reported by other authors as well (Latocha, Łata and Stasiak, 2015; Latocha 2017; Latocha et al., 2013; Nishiyama et al., 2004; Cesoniene, Daubaras and Viskelis, 2004). For the present study, the highest value was found for 'Issai' in 2018 with fruits containing $141.4 \mathrm{mg}$ per $100 \mathrm{~g}$ of FW (Table 2 and 3). Some smaller levels were found for 'Soreli' in the same year. Out of the studied varieties, 'Ananasnaya' exhibited the lowest ascorbic acid levels in both years of study.

Antioxidant activity was studied using two methods FRAP and DPPH. The results confirmed that for both Actinidia chinensis and Actinidia arguta, fruits are a good source of antioxidants compared with other fruit species found in the moderate climate zone. In terms of pulp, the highest values were measured for the variety of 'Soreli' when the FRAP method marked the level of 1.283 and the DPPH technique detected the level of 1.309 (Table 2). While the kiwi fruit skin exhibited a higher concentration of substances with antioxidant effects in any of the cases, at the species level, a significant difference was detected between $A$. arguta and $A$. chinensis. The commercially available varieties of 'Soreli' and 'Hayward' showed to have the antioxidant activity 2-3 times higher in the skin compared with the pulp, and the A. arguta skin exhibited more than 15 times the concentration as the one observed for the pulp (Table 2). These results match those achieved by other authors (Latocha et al. 2013; An et al., 2016; Leontowicz et al., 2016).

Table 2 Concentration of organic acids and antioxidant activity in Actinidia fruit pulp

\begin{tabular}{|c|c|c|c|c|c|c|c|}
\hline \multirow[t]{2}{*}{ Species } & \multirow[t]{2}{*}{ Variety } & \multirow[t]{2}{*}{ Year } & \multirow{2}{*}{$\begin{array}{c}\text { Malic acid } \\
\left(\mathrm{g} .100 \mathrm{~g} \mathrm{FW}^{-1}\right)\end{array}$} & \multirow{2}{*}{$\begin{array}{c}\text { Citric acid } \\
\left(\mathrm{g} .100 \mathrm{~g} \mathrm{FW}^{-1}\right)\end{array}$} & \multirow{2}{*}{$\begin{array}{c}\text { Ascorbic acid } \\
\left(\mathrm{mg.100}^{\left.-10 W^{-1}\right)}\right.\end{array}$} & \multicolumn{2}{|c|}{ Antioxidant activity $\left(\mathrm{mmol} \mathrm{TE.I^{-1 } )}\right.$} \\
\hline & & & & & & FRAP & DPPH \\
\hline \multirow{4}{*}{$\begin{array}{l}\text { Actinidia } \\
\text { arguta }\end{array}$} & 'Ananasnaya' & 2018 & $4.34 \pm 0.68^{e}$ & $8.93 \pm 0.98^{e}$ & $38.7 \pm 2.21^{\mathrm{a}}$ & $0.64 \pm 0.20^{d}$ & $0.73 \pm 0.18^{c}$ \\
\hline & 'Issai' & 2018 & $4.66 \pm 0.32^{\mathrm{e}}$ & $8.69 \pm 0.71^{\mathrm{e}}$ & $141.4 \pm 16.3^{d}$ & $0.93 \pm 0.29^{e}$ & $0.75 \pm 0.07^{c}$ \\
\hline & 'Ananasnaya' & 2019 & $3.72 \pm 0.47^{d}$ & $7.66 \pm 1.73^{c}$ & $57.6 \pm 14.2^{b}$ & $0.48 \pm 0.05^{b}$ & $0.55 \pm 0.05^{\mathrm{a}}$ \\
\hline & 'Issai' & 2019 & $3.67 \pm 1.37^{d}$ & $8.02 \pm 2.09^{d}$ & $72.8 \pm 18.0^{c}$ & $0.66 \pm 0.16^{d}$ & $0.64 \pm 0.13^{b}$ \\
\hline \multirow{4}{*}{$\begin{array}{l}\text { Actinidia } \\
\text { chinensis }\end{array}$} & 'Hayward' & 2018 & $2.14 \pm 0.69^{\mathrm{a}}$ & $6.82 \pm 1.43^{\mathrm{ab}}$ & $52.0 \pm 12.6^{b}$ & $0.41 \pm 0.11^{\mathrm{a}}$ & $0.56 \pm 0.19^{\mathrm{a}}$ \\
\hline & 'Soreli' & 2018 & $3.04 \pm 0.56^{c}$ & $7.56 \pm 0.46^{c}$ & $134.0 \pm 21.5^{\mathrm{d}}$ & $1.283 \pm 0.10^{f}$ & $1.31 \pm 0.07^{\mathrm{e}}$ \\
\hline & 'Hayward' & 2019 & $2.60 \pm 0.79^{b}$ & $7.03 \pm 0.84^{b}$ & $75.1 \pm 11.9^{c}$ & $0.58 \pm 0.11^{c}$ & $0.71 \pm 0.13^{c}$ \\
\hline & 'Soreli' & 2019 & $1.93 \pm 0.45^{\mathrm{a}}$ & $6.64 \pm 1.27^{\mathrm{a}}$ & $73.0 \pm 13.6^{c}$ & $0.89 \pm 0.24^{e}$ & $0.98 \pm 0.24^{d}$ \\
\hline
\end{tabular}

Different uppercase letters next to values indicate significant differences in columns $(P<0.05)$

Table 3 Concentration of organic acids and antioxidant activity in Actinidia fruit skin

\begin{tabular}{|c|c|c|c|c|c|c|c|}
\hline \multirow[t]{2}{*}{ Species } & \multirow[t]{2}{*}{ Variety } & \multirow[t]{2}{*}{ Year } & \multirow{2}{*}{$\begin{array}{c}\text { Malic acid } \\
\left(\mathrm{g} .100 \mathrm{~g} \mathrm{FW}^{-1}\right)\end{array}$} & \multirow{2}{*}{$\begin{array}{c}\text { Citric acid } \\
\left(\mathrm{g} .100 \mathrm{~g} \mathrm{FW}^{-1}\right)\end{array}$} & \multirow{2}{*}{$\begin{array}{c}\text { Ascorbic acid } \\
\left(\mathrm{mg} .100 \mathrm{~g} \mathrm{FW}^{-1}\right)\end{array}$} & \multicolumn{2}{|c|}{ Antioxidant activity (mmol TE. ${ }^{-1}$ ) } \\
\hline & & & & & & FRAP & DPPH \\
\hline \multirow{4}{*}{$\begin{array}{l}\text { Actinidia } \\
\text { arguta }\end{array}$} & 'Ananasnaya' & 2018 & $3.16 \pm 0.67^{\mathrm{ab}}$ & $5.34 \pm 0.79^{c}$ & $24.5 \pm 12.5^{b c}$ & $8.51 \pm 3.13^{d}$ & $10.33 \pm 1,43^{e}$ \\
\hline & 'Issai' & 2018 & $3.83 \pm 0.92^{b}$ & $6.64 \pm 0.46^{d}$ & $18.8 \pm 7.3^{b}$ & $11.27 \pm 2.28^{\mathrm{e}}$ & $14.18 \pm 1.44^{f}$ \\
\hline & 'Ananasnaya' & 2019 & $2.76 \pm 0.64^{\mathrm{a}}$ & $4.59 \pm 0.95^{b}$ & $33.5 \pm 6.29^{c}$ & $6.18 \pm 1.34^{d}$ & $7.81 \pm 1.70^{d}$ \\
\hline & 'Issai' & 2019 & $3.37 \pm 0.32^{b}$ & $6.83 \pm 0.94^{d}$ & $55.0 \pm 10.3^{d}$ & $10.12 \pm 1.68^{\mathrm{e}}$ & $12.39 \pm 2.15^{\mathrm{e}}$ \\
\hline \multirow{4}{*}{$\begin{array}{l}\text { Actinidia } \\
\text { chinensis }\end{array}$} & 'Hayward' & 2018 & $4.06 \pm 0.10^{c}$ & $4.32 \pm 0.56^{b}$ & $8.6 \pm 0.7^{\mathrm{a}}$ & $1.13 \pm 0.15^{\mathrm{a}}$ & $0.98 \pm 0.13^{\mathrm{a}}$ \\
\hline & 'Soreli' & 2018 & $4.56 \pm 0.97^{c}$ & $5.54 \pm 0.91^{c}$ & $24.2 \pm 0.7^{b}$ & $3.83 \pm 0.12^{c}$ & $3.31 \pm 0.63^{c}$ \\
\hline & 'Hayward' & 2019 & $3.37 \pm 0.85^{b}$ & $3.88 \pm 0.56^{\mathrm{a}}$ & $5.2 \pm 4.3^{\mathrm{a}}$ & $1.16 \pm 0.14^{\mathrm{a}}$ & $1.73 \pm 0.11^{b}$ \\
\hline & 'Soreli' & 2019 & $2.37 \pm 0.30^{\mathrm{a}}$ & $3.52 \pm 0.32^{\mathrm{a}}$ & $14.0 \pm 7.4^{\mathrm{ab}}$ & $2.32 \pm 0.18^{b}$ & $3.27 \pm 0.19^{c}$ \\
\hline
\end{tabular}




\section{Conclusion}

As a species, Actinidia arguta is undoubtedly a very prospective species of kiwi; one that extends the scope of application of the genus as such to the colder regions. Even despite the smaller size, the fruits are tasty and refreshing; they contain a well-balanced proportion of not only sugars and acids, but also substances with antioxidant effects. The smooth skin of the fruits is a great advantage as it is not necessary to be removed prior to eating. It is precisely the high antioxidant potential in the skin which provides a good indicator of the fact that in terms of nutritional composition, A. arguta fruits outdo even normally commercially available fruit of $A$. chinensis, more specifically, the 'Hayward' a 'Soreli' varieties. The content of vitamin $C$, or, ascorbic acid, in kiwi fruits is considerably high; in particular, the 'Issai' variety has a high level in the pulp when the studied fruits contained over $140 \mathrm{mg}$ per $100 \mathrm{~g}$ of FW. In terms of soluble solids and titratable acidity of fruits, the two kiwi species seemed to be consistent with each other except that the $A$. arguta fruit is more typical with its slightly higher content of titratable acidity, which is largely evident through citric acid as the prevailing type of acid that reached over $8 \mathrm{~g}$ per $\mathrm{kg}$ of FW in some of the samples. For a fruit crop grower, $A$. arguta presents, as a species, a definitely attractive alternative to traditional fruit species of colder zones, such as apple, pear, cherry etc. With its notable aromatic manifestation featuring a distinct taste of tropical fruits as well as the well-balanced proportion of sugars and acids, the popularity of the species is sure to rise as evidenced through the increase in scientific studies focusing precisely on the research in the health-beneficial bioactive substances contained in kiwiberry. A. arguta could also be a promising species for the processing industry, since it is not necessary to remove the skin from fruits. The disadvantage of these fruits is more difficult harvesting, to determine the exact date of harvest it is necessary to know the physical characteristics of each variety. The gradual ripening of the fruit also complicates the harvest.

\section{Acknowledgement}

Financial support for this research was provided by the project IGA-ZF/2018-AP003 of the Mendel University in Brno, Czech Republic.

\section{References}

AN, X. - LEE, S.G. - KANG, H. - HEO, H.J. - CHO, Y.S. - DO, K. 2016 Antioxidant and anti-inflammatory effects of various cultivars of kiw berry (Actinidia arguta) on lipopolysaccharide-stimulated RAW 264.7 cells. In J. Microbiol. Biotechnol., vol. 26, 2016, no. 8, pp. 1367-1374.

BOYES, S. - STRÜBI, P. - MARSH, H. 1996. Sugar and organic acid analysis of Actinidia arguta and rootstock-scion combinations of Actinidia arguta Lebensm. In Wiss.Technol., vol. 30, 1996, pp. 390-397. CESONIENE, L. - DAUBARAS, R. - VISKELIS, P. 2004. Biochemical composition of berries of some kolomicta kiwi (Actinidia kolomicta) cultivars and detection of harvest maturity. In Acta Hortic, vol. 663, 2004, pp. 305-308.

DAWES, H.M. - KEENE, J.B. 1999. Phenolic composition of kiwifruit juice. In J. Agric. Food Chem., vol. 47, 1999, pp. 2398-2403. DEBERSAQUES, F. - MEKERS, O. - DECORTE, J. - VAN LABEKE, M.C. SCHOEDL-HUMMEL, K. - LATOCHA, P. 2015. Challenges faced by commercial kiwiberry (Actinidia arguta Planch.) production. In Acta
Hortic., vol. 1096, 2015, pp. 435-442. https://doi.org/10.17660/ ActaHortic.2015.1096.52

DRZEWIECKI, J. - LATOCHA, P. - LEONTOWICZ, H. - LEONTOWICZ, M. - PARK, Y.S. - NAJMAN, K. - WEISZ, M. - EZRA, A. - GORINSTEIN, S. 2016. Analytical methods applied to characterization of Actinidia arguta, Actinidia deliciosa, and Actinidia eriantha kiwi fruit cultivars. In Food Anal. Method, vol. 9, 2016, pp.1353-1366.

FERGUSON, A.R. - FERGUSON, L.R. 2003. Are kiwifruit really good for you. In Acta Horit. vol. 610, 2003, pp.132-138.

FERGUSON, A.R. - TESTOLIN, R. - HUANG, A.H. 2016. The kiwifruit genome. Botanical description (Eds.), Series Title: Compendium of Plant Genomes, Publisher : Springer, 2016, pp. 1-14. ISBN 978-3-319-32272-8. KRUPA, T. - LATOCHA, P. - LIWIN'SKA, A. 2011. Changes of physicochemical quality, phenolics and vitamin $C$ content in hardy kiwifruit (Actinidia arguta and its hybrid) during storage. In Scientia Horticulturae, vol. 130, 2011, pp. 410-417.

LATOCHA, P. - WOŁOSIAK, R. - WOROBIEJ, E. - KRUPA, T. 2013. Clonal differences in antioxidant activity and bioactive constituents of hardy kiwifruit (Actinidia arguta) and its year-to-year variability. In J. Sci. Food Agric., vol. 93, 2013, pp. 1412-1419.

LATOCHA, P. - ŁATA, B. - STASIAK A. 2015. Phenolics, ascorbate and the antioxidant potential of kiwiberry vs. common kiwifruit: The effect of cultivar and tissue type. In J. Funct. Foods, vol. 19, 2015, pp. 155-163. doi:10.1016/j.jff.2015.09.024

LATOCHA, P. 2017. The nutritional and health benefits of kiwiberry (Actinidia arguta) - a review. In Plant Foods Hum. Nutr., vol. 72, pp. 325-334.

LATOCHA, P. - VEREECKE, D. - DEBERSAQUES, F. 2018. Kiwiberry commercial production - what stage are we at? In Acta Hortic., vol. 1218, 2018, pp. 559-564. DOI: 10.17660/ActaHortic.2018.1218.76

LEONTOWICZ, H. - LEONTOWICZ, M. - LATOCHA, P. - JESION, PARK, Y.S. - KATRICH, E. - BARASCH, D. - NEMIROVSKI, A. GORINSTEIN, S. 2016. Bioactivity and nutritional properties of hardy kiwi fruit Actinidia arguta in comparison with Actinidia deliciosa "Hayward" and Actinidia eriantha 'Bidan'. In Food Chem., vol. 196, 2016, pp. 281-291.

LIM, T.K. 2012. Actinidia arguta. In Edible Medicinal and NonMedicinal Plants, Fruits (Dordrecht, The Netherlands: Springer), 2012, pp. 5-11.

NISHIYAMA, I. - YAMASHITA, Y. - YAMANAKA, M. - SHIMOHASHI, A. - FUKUDA T. - OOTA, T. 2004. Varietal difference in vitamin C content in the fruit of kiwifruit and other Actinidia species. In J. Agric. Food Chem., vol. 52, 2004, pp. 5472-5475.

NISHIYAMA, I. - FUKUDA, T. - OOTA, T. 2005. Genotypic differences in chlorophyll, lutein, and $\beta$-carotene contents in the fruits of Actinidia species. J. Agric. Food Chem., vol. 53, 2005, pp. 6403-6407.

RUSH, E. - FERGUSON, L.R. - CUMIN, M. - THAKUR, V. KARUNASINGHE, N. - PLANK, L. 2006. Kiwifruit consumption reduces DNA fragility: a randomized controlled pilot study in volunteers. In Nutr. Res., vol. 26, 2006, pp. 197-201.

WHITE, A. - NIHAL DE SILVA, H. - REQUEJO TAPIA, C. - HARKER, F. R. 2005. Evaluation of softening characteristics of fruit from 14 species of Actinidia. In Postharvest Biology and Technology, vol. 35, 2005, pp. 143-151.

WOJDYŁO, A. - NOWICKA, P. - OSZMIAŃSKI, J. - GOLIS, T. 2017. Phytochemical compounds and biological effects of Actinidia fruits. In J. Funct. Foods. vol. 30, 2017, pp. 194-202. https://doi. org/10.1016/j.jff.2017.01.018

ZAOUAY, F. - MENA, P. - GARCIA VIGUERA, C. - MARS, M. 2012. Antioxidant activity and physico-chemical properties of Tunisian grown pomegranate (Punica granatum L.) cultivars. In Industrial Crops and Products, vol. 40, 2012, pp. 81-89.

ZHOU-LI, Z. - PING MAN, Y. - YAN LAN, X. - CHANG, W.Y. 2013. Ploidy and phenotype variation of a natural Actinidia arguta population in the east of Daba Mountain located in a region of Shaanxi. In Scientia Horticulturae, vol. 161, 2013, pp. 259-265. ISSN 0304-4238. 